\title{
Barriers Rural Physicians Face Prescribing Buprenorphine for Opioid Use Disorder
}

\author{
C. Holly A. Andrilla, MS \\ Cyntbia Coulthard, MPH \\ Eric H. Larson, PbD
}

WWAMI Rural Health Research Center, Department of Family Medicine, University of Washington School of Medicine, Seattle, Washington

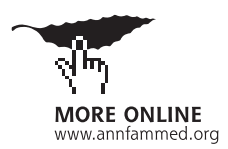

Conflicts of interest: authors report none.

\section{CORRESPONDING AUTHOR}

C. Holly A. Andrilla, MS WWAMI Rural Health Research Center Department of Family Medicine Box 354982

University of Washington Seattle, WA 98195-4696 hollya@uw.edu

\begin{abstract}
Opioid use disorder is a serious public health problem. Management with buprenorphine is an effective, office-based, medication-assisted treatment, but $60.1 \%$ of rural counties in the United States lack a physician with a Drug Enforcement Agency waiver to prescribe buprenorphine. This national study surveyed all rural physicians who have received a waiver in the United States and found that those who were not actively prescribing buprenorphine reported significantly more barriers than those who were, regardless of whether they were treating the maximum number of patients their waiver allowed. These findings suggest the need for tailored strategies to address barriers to providing buprenorphine for opioid use disorder and to support physicians who are adding or maintaining this service.
\end{abstract}

Ann Fam Med 2017;15:359-362. https://doi.org/10.1370/afm.2099.

\section{INTRODUCTION}

T

The opioid abuse epidemic is a serious and persistent public health problem. In 2015 an estimated 2.0 million people had a pain reliever use disorder, and 828,000 people had used heroin in the previous year. ${ }^{1}$ Buprenorphine maintenance treatment is effective for opioid use disorder, ${ }^{2}$ and major efforts have been made to expand its availability. The Drug Addiction Treatment Act of 2000 allows physicians who complete training to obtain a Drug Enforcement Agency (DEA) waiver that permits prescribing buprenorphine to treat opioid use disorder. Despite a more than threefold increase in the number of physicians with a DEA waiver since $2006,{ }^{3} 60.1 \%$ of rural counties lack a physician with a waiver. ${ }^{4}$ Access to treatment continues to be a challenge for rural populations. Many physicians with a waiver are not using it to its full extent or at all. ${ }^{5,6}$

A few studies, limited to 1 or only a few states, have looked at the barriers physicians face providing buprenorphine maintenance treatment, but none has examined nationally the differences between physician groups who are and are not actively using their waivers or accepting new patients. ${ }^{7-10}$ This study's purpose was to understand the barriers physicians with waivers face in providing buprenorphine maintenance treatment.

\section{METHODS}

We surveyed all rurally located physicians in the United States on the DEA list (April 2016) who had received waivers to prescribe buprenorphine. We categorized physicians as rural using the Federal Information Processing Standards county code of the physicians' address if they had an Urban Influence Code of 3 through 12."

We mailed paper questionnaires (Supplemental Questionnaire available at http://www.AnnFamMed.org/content/15/4/359/DC1) and invitations to respond online to all physicians at the addresses in the DEA file. We used the American Medical Association Physician Masterfile and physicians' National Provider Identifier numbers ${ }^{12}$ to correct addresses for nonresponding physicians and returned questionnaires. Research staff telephoned all 
Table 1. Characteristics of Physicians With a Drug Enforcement Agency Waiver to Prescribe Buprenorphine for the Treatment of Opioid Use Disorder, by Prescribing Category

\begin{tabular}{|c|c|c|c|c|c|c|}
\hline Characteristic & Overall & $\begin{array}{l}\text { Never a } \\
\text { Prescriber }\end{array}$ & $\begin{array}{c}\text { Former } \\
\text { Prescriber }\end{array}$ & $\begin{array}{c}\text { Current Prescriber } \\
\text { Not Accepting } \\
\text { New Patients }\end{array}$ & $\begin{array}{c}\text { Current Prescriber } \\
\text { Accepting } \\
\text { New Patients }\end{array}$ & $P$ Value ${ }^{d}$ \\
\hline No. & 1,124 & 124 & 197 & 129 & 674 & \\
\hline \multicolumn{7}{|l|}{ Age, y } \\
\hline Mean & 56.2 & 55.6 & 55.8 & 57.1 & 56.3 & .686 \\
\hline$<35, \%$ & 3.7 & 6.8 & 3.7 & 2.4 & 3.4 & .336 \\
\hline $36-55, \%$ & 41.0 & 37.3 & 41.9 & 44.4 & 40.8 & \\
\hline $56-65, \%$ & 34.1 & 40.7 & 35.6 & 29.8 & 33.2 & \\
\hline$>65, \%$ & 21.2 & 15.3 & 18.8 & 23.4 & 22.5 & \\
\hline Sex, male, \% & 75.1 & 79.7 & 69.8 & 72.6 & 76.4 & .157 \\
\hline Region & & & & & & .049 \\
\hline Northeast, \% & 24.1 & 23.4 & 20.8 & 30.2 & 24.0 & \\
\hline Midwest, \% & 20.4 & 27.4 & 22.3 & 16.3 & 19.3 & \\
\hline South, $\%$ & 34.1 & 33.1 & 38.6 & 25.6 & 34.6 & \\
\hline West, \% & 21.4 & 16.1 & 18.3 & 27.9 & 22.1 & \\
\hline Specialty & & & & & & $<.001$ \\
\hline Family medicine, \% & 43.3 & 35.5 & 37.1 & 46.5 & 46.0 & \\
\hline Psychiatry, \% & 18.6 & 29.8 & 24.4 & 16.3 & 15.3 & \\
\hline Internal medicine, \% & 10.3 & 5.6 & 12.7 & 15.5 & 9.5 & \\
\hline Other, \% & 27.8 & 29.0 & 25.9 & 21.7 & 29.2 & \\
\hline Practice type, private, $\%$ & 38.6 & 21.5 & 20.6 & 51.7 & 43.5 & $<.001$ \\
\hline Waiver type & & & & & & $<.001$ \\
\hline 30 patients, \% & 55.8 & 93.5 & 77.7 & 55.0 & 42.6 & \\
\hline 100 patients, \% & 44.2 & 6.5 & 22.3 & 45.0 & 57.4 & \\
\hline $\begin{array}{l}\text { Note: Percentages within cate } \\
\text { a Have prescribed buprenorph } \\
\text { b Have prescribed buprenorph } \\
\text { of their waiver). } \\
\text { ' Currently treating patients, a } \\
\text { d Overall 4-category } \chi^{2} \text { test. }\end{array}$ & $\begin{array}{l}\text { ries may not } \\
\text { e, but not cur } \\
\text { l accepting ne }\end{array}$ & $\begin{array}{l}\text { tal } 100 \text { because } \\
\text { ntly treating pat } \\
\text { treating patient } \\
\text { opioid use disor }\end{array}$ & $\begin{array}{l}\text { rounding. Missing } \\
\text { its, or accepting } n \\
\text { but not accepting } \\
\text { r patients. }\end{array}$ & $\begin{array}{l}\text { ta: age, } n=47 ; \text { sex, } n=4 \\
\text { opioid use disorder patients } \\
W \text { opioid use disorder patier }\end{array}$ & $\begin{array}{l}\text { practice type, } n=243 \text {. } \\
\text { (may or may not have reach }\end{array}$ & the patient lim \\
\hline
\end{tabular}

nonrespondents using DEA, American Medical Association, National Provider Identifier, or Google Search result addresses until the physician's practice was found. Participants received the questionnaire at that address twice more, 2 weeks apart, followed by an abbreviated version of the questionnaire as a tear-off return postcard 1 month after follow-up began. Physicians responding to the tear-off postcard were not asked the barriers question. We telephoned nonrespondents up to 3 times, at 2-week intervals. Data collection occurred from July through November 2016.

Physicians were classified into 4 categories based on whether they had ever prescribed buprenorphine to treat opioid use disorder, whether they were currently prescribing buprenorphine maintenance treatment, and whether they were accepting new patients with opioid use disorder. Physicians who could not be categorized because of missing survey data were excluded $(n=97)$. To determine the significance of our findings, we performed $\chi^{2}$ tests, Fisher exact tests, and analysis of variance using IBM SPSS 24.0 (International Business Machines Corp).
The University of Washington Institutional Review Board approved this research.

\section{RESULTS}

Of the 2,577 physicians surveyed, $60.5 \%$ responded $_{i}$ 539 were determined not to be practicing, were practicing in an urban location, or were otherwise out of scope of the study. Respondents and nonrespondents did not differ by age, sex, or employment. Physicians in the West responded at a higher rate $73.3 \%$, $P<.001$ ) than others (Northeast, $60.2 \%$; Midwest, $65.8 \%$; South, $57.8 \%$ ). A higher percentage of physicians who had received waivers to treat up to 100 patients concurrently $(65.4 \%, P<.001)$ responded than did physicians who received waivers to treat 30 patients $(57.5 \%)$.

Table 1 displays characteristics of the 4 physician groups: never prescribers, former prescribers, current prescribers not accepting new patients, and current prescribers accepting new patients. 
The questionnaire asked physicians to indicate from a list of issues whether each was a barrier to incorporating buprenorphine maintenance treatment into their practice. Respondents could also indicate an additional barrier and provide a text response. Concerns about diversion or medication misuse, time constraints, and lack of available mental health or psychosocial support services were cited most frequently across all waiver-use categories (Table 2). Nonprescribers (never and former prescribers) reported the following barriers significantly more often than current prescribers (not shown): time constraints $(P=.003)$, lack of patient need $(P=.002)$, resistance from practice partners $(P<.001)$, lack of specialty backup for complex problems $(P<.002)$, lack of confidence in their ability to manage opioid use disorders $(P<.001)$, concerns about DEA intrusions on their practice $(P=.028)$, and attraction of drug users to their practice $(P<.001)$.

Among physicians reporting other barriers $(n=205)$, reported themes included administrative or infrastructure issues, eg, told they cannot do it or do not have the space or staff (17.6\%), regulatory hurdles including prior authorization and paperwork (16.6\%), difficult patients (11.7\%), and stigma (9.3\%).

\section{DISCUSSION}

Diversion has been discussed in $1 \mathrm{study}^{7}$ and financial concerns have been cited in 3. ${ }^{8-10}$ The only other national survey of physicians providing buprenorphine maintenance treatment ${ }^{13}$ found that physicians with waivers whose names were found on a public locator list and those whose names were not reported financial concerns $(59.3 \%$ and $71.8 \%$, respectively), more often than they reported diversion concerns $(18.7 \%$ and $26.3 \%$ respectively). Our findings show the opposite trend: more physicians, regardless of prescribing status, were concerned about diversion than finances. These differences may be due to the lack of urban physicians in our study. Our national estimates may be biased because of the higher response rates of physicians in the West and physicians with a waiver to treat 100 patients.

Solutions to improve rural patient's access to buprenorphine maintenance treatment must be multipronged to encourage physicians to add or maintain this service, including targeting former prescribers. Most former prescribers held 100-patient limit waivers, which, if reactivated, would provide the maximum number of additional treatment slots. Several barriers affecting nonprescribers more than prescribers were practice

Table 2. Physicians' Barriers to Incorporating Buprenorphine Maintenance Treatment Into Clinical Practice, by Prescribing Category

\begin{tabular}{|c|c|c|c|c|c|c|}
\hline Barrier & Overall & $\begin{array}{l}\text { Never a } \\
\text { Prescriber }\end{array}$ & $\begin{array}{l}\text { Former } \\
\text { Prescriber }^{\mathrm{a}}\end{array}$ & $\begin{array}{c}\text { Current Prescriber } \\
\text { Not Accepting } \\
\text { New Patients }\end{array}$ & $\begin{array}{c}\text { Current Prescriber } \\
\text { Accepting } \\
\text { New Patientsc }\end{array}$ & $\begin{array}{c}P \\
\text { Value }^{d}\end{array}$ \\
\hline No. & 1,124 & 124 & 197 & 129 & 674 & \\
\hline Time constraints, \% & 40.2 & 45.6 & 52.1 & 43.5 & 35.8 & .008 \\
\hline Lack of patient need, $\%$ & 2.4 & 9.3 & 4.3 & 1.9 & 1.3 & $.003^{e}$ \\
\hline Financial/reimbursement concerns, \% & 28.6 & 18.9 & 31.6 & 17.0 & 31.6 & .007 \\
\hline Resistance from practice partner, \% & 13.6 & 21.8 & 30.2 & 8.8 & 9.6 & $<.001$ \\
\hline $\begin{array}{l}\text { Lack of specialty backup for com- } \\
\text { plex problems, \% }\end{array}$ & 31.5 & 40.0 & 45.3 & 34.9 & 26.3 & $<.001$ \\
\hline $\begin{array}{l}\text { Lack of confidence in ability to } \\
\text { manage opioid use disorder, \% }\end{array}$ & 9.6 & 38.2 & 11.2 & 9.4 & 5.8 & $<.001$ \\
\hline $\begin{array}{l}\text { Lack of available mental health or } \\
\text { psychosocial support services, \% }\end{array}$ & 44.4 & 48.1 & 50.4 & 49.1 & 41.4 & .192 \\
\hline $\begin{array}{l}\text { Attraction of drug users to your } \\
\text { practice, } \%\end{array}$ & 30.5 & 38.5 & 51.7 & 35.2 & 23.3 & $<.001$ \\
\hline DEA intrusion, \% & 13.8 & 18.5 & 19.1 & 14.2 & 11.9 & .158 \\
\hline $\begin{array}{l}\text { Diversion or misuse of medication } \\
\text { concerns, } \%\end{array}$ & 48.4 & 42.6 & 53.0 & 55.8 & 46.3 & .185 \\
\hline \multicolumn{7}{|l|}{ DEA = Drug Enforcement Administration. } \\
\hline $\begin{array}{l}\text { Note: Missing data: time, } n=373 \text {; patient } \\
\text { health services, } n=376 \text {; attraction of drug } \\
\text { a Have prescribed buprenorphine, but not } \\
{ }^{b} \text { Have prescribed buprenorphine, currently } \\
\text { their waiver). } \\
\text { ' Currently treating patients and accepting } \\
{ }^{d} \text { Overall } 4 \text {-category } \chi^{2} \text { test. } \\
\text { e Fisher exact test. }\end{array}$ & $\begin{array}{l}\text { ed, } \mathrm{n}=379 ; \\
\text { sers, } \mathrm{n}=384 \\
\text { rently treatir } \\
\text { reating patie } \\
\text { w opioid use }\end{array}$ & $\begin{array}{l}\text { inancial, } n=380 \\
\text { DEA intrusion, } n \\
g \text { patients or acce } \\
\text { ts, but not accept } \\
\text { disorder patients. }\end{array}$ & $\begin{array}{l}\text { esistance, } n=391 \\
386 ; \text { diversion, } n \\
\text { ting new opioid us } \\
\text { g new opioid use }\end{array}$ & $\begin{array}{l}\text { specialty backup, } n=379 \\
477 \text {. } \\
\text { disorder patients. } \\
\text { isorder patients (may or ma }\end{array}$ & $\begin{array}{l}\text { nfidence, } \mathrm{n}=381 \text {; available } \\
\text { not have reached the patien }\end{array}$ & $\begin{array}{l}\text { nental } \\
\text { limit of }\end{array}$ \\
\hline
\end{tabular}


related, including resistance from practice partners and attraction of drug users to their practice. Practice-level interventions may be possible to encourage nonprescribers to add buprenorphine maintenance treatment.

Certain highly cited barriers cut across prescribing groups. Further study of the large number of physicians who have successfully overcome these barriers is needed to identify best practices to help other physicians successfully add or maintain buprenorphine maintenance treatment.

To read or post commentaries in response to this article, see it online at http://www.AnnFamMed.org/content/15/4/359.

Key words: buprenorphine; opiate substitution treatment; rural health; mental health care; opiate addiction; opioid treatment programs; medication-assisted treatment

Submitted January 31, 2017; submitted, revised, May 2, 2017; accepted May 9, 2017.

Funding support: This study was supported by the Federal Office of Rural Health Policy, Health Resources and Services Administration, US Department of Health and Human Services.

Supplementary materials: Available at http://www.AnnFamMed. org/content/15/4/359/DC1.

\section{References}

1. Substance Abuse and Mental Health Services Administration (SAMHSA). Key substance use and mental health indicators in the United States: Results from the 2015 national survey on drug use and health. https://www.samhsa.gov/data/sites/default/files/NSDUHFFR1-2015/NSDUH-FFR1-2015/NSDUH-FFR1-2015.pdf. Published Sep 2016. Accessed Aprl 25, 2017.

2. Thomas $C P$, Fullerton $C A$, Kim M, et al. Medication-assisted treatment with buprenorphine: assessing the evidence. Psychiatr Serv. 2014;65(2):158-170.
3. Stein BD, Pacula RL, Gordon AJ, et al. Where is buprenorphine dispensed to treat opioid use disorders? The role of private offices, opioid treatment programs, and substance abuse treatment facilities in urban and rural counties. Milbank Q. 2015;93(3):561-583.

4. Andrilla CHA, Coulthard C, Larson EH. Changes in the Supply of Physicians With a DEA DATA Waiver to Prescribe Buprenorphine for Opioid Use Disorder. Data Brief \#162. Seattle, WA: WAMI Rural Health Research Center; 2017.

5. Rosenblatt RA, Andrilla CHA, Catlin M, Larson EH. Geographic and specialty distribution of US physicians trained to treat opioid use disorder. Ann Fam Med. 2015;13(1):23-26.

6. Walley AY, Alperen JK, Cheng DM, et al. Office-based management of opioid dependence with buprenorphine: clinical practices and barriers. J Gen Intern Med. 2008;23(9):1393-1398.

7. Quest TL, Merrill JO, Roll J, Saxon AJ, Rosenblatt RA. Buprenorphine therapy for opioid addiction in rural Washington: the experience of the early adopters. J Opioid Manag. 2012;8(1):29-38.

8. Hutchinson E, Catlin M, Andrilla CHA, Baldwin LM, Rosenblatt RA. Barriers to primary care physicians prescribing buprenorphine. Ann Fam Med. 2014;12(2):128-133.

9. DeFlavio JR, Rolin SA, Nordstrom BR, Kazal LA Jr. Analysis of barriers to adoption of buprenorphine maintenance therapy by family physicians. Rural Remote Health. 2015;15:3019.

10. Li X, Shorter D, Kosten TR. Buprenorphine in the treatment of opioid addiction: opportunities, challenges and strategies. Expert Opin Pharmacother. 2014;15(15):2263-2275.

11. US Department of Agriculture Economic Research Service. Urban Influence Codes. https://www.ers.usda.gov/data-products/urbaninfluence-codes/. Updated May 10, 2013. Accessed Apr 22, 2016.

12. National Plan and Provider Enumeration System (NPPES). National Provider Identifier (NPI). https://npiregistry.cms.hhs.gov/. Accessed Jan 2016-Nov 2016.

13. Arfken CL, Johanson CE, di Menza S, Schuster CR. Expanding treatment capacity for opioid dependence with office-based treatment with buprenorphine: National surveys of physicians. J Subst Abuse Treat. 2010;39(2):96-104. 